\title{
REALIDADE DA EDUCAÇÃO FÍSICA ESCOLAR
}

Ephigênia Sáes CACERES* Néli da Silva MENDONÇA*

Em primeiro lugar, temos que agradecer esta oportunidade que a USP está nos dando, porque uma necessidade premente que nós, do Sistema Estadual de Educação, sentimos, é desses momentos de debates mais amplos.

Se a fala do Professor Guilmar teve uma finalidade de mexer nas bases e suscitar dúvidas, acredito que ele conseguiu. E diria:

- Você tentou construir um castelo, mas acho que com 30 anos de magistério, constroem-se e reconstroem-se castelos. Vamos construir casebres, mas vamos caminhar juntos com as Universidades e realmente tentar colocar a Educação Física no seu devido lugar.

Acho que não é pela Educação Física ter um tratamento de atividade ou de disciplina que ela se encontra nesse marasmo, mas sim pela nossa própria formação, pelo caminho que não sabemos aonde ir. Mesmo representando um órgão oficial de pesquisas e normas pedagógicas, apresentamos muitas dúvidas. Imagine agora, como estarão esses professores recém egressos de uma universidade, enfrentando a luta diária.

O Sistema Estadual de Educação é muito amplo e a quantidade de professores que temos no momento é de 25 a $30 \mathrm{mil}$, distribuídos por seis mil escolas, efetivamente oficiais e por outras seis mil, organizadas de forma aleatória. No Estado de São Paulo temos praticamente doze mil escolas. Então vejam, como fica difícil chegar a este profissional que saiu ontem da universidade, ou àqueles que já estão trabalhando há 20 ou 25 anos para atualizá-lo. Neste momento, a professora Néli fará uma exposição onde serão levantados alguns problemas que acreditamos merecer reflexões, principalmente desta Universidade, da qual estamos muito perto. Abordaremos alguns aspectos para ver qual é a contribuição desta Universidade para trabalhar junto com a rede estadual de ensino.

Agradeço também a esta Universidade, essa realização e me sinto muito feliz. por poder participar deste Simpósio e de mostrar a nossa realidade.

No diagnóstico que temos da rede estadual de ensino, enfatizamos dois aspectos fundamentais: um é a questão da política educacional e o outro é a formação do profissional.

Quanto à política educacional, gostaria de salientar o seguinte: hoje ela está preocupada com a demanda do aluno e não com a qualidade de ensino. Por isso as escolas estão sendo ampliadas e reestruturadas, como afirmou a professora Ephigênia. Dessas 12 mil escolas existentes, 50\% são planejadas e $50 \%$ são criadas, porém não planejadas, e portanto sem espaço físico suficiente para um atendimento digno dos alunos.

Antigamente existiam Grupos Escolares, onde não havia quadra para as aulas de Educação Física, com a reestruturação, esses prédios passaram a funcionar como Escolas de 10. grau ou de 10. e 20. graus. Se não existia espaço para o (irupo, que era de 1a. à 4a. série, imagine agora que será de 1a. à 8a. série e até de 20 . grau. Um outro problema que temos também é a ampliação da jornada de trabalho do professor de Educação Física, que atuará no Ciclo Básico. Esclarecemos que essas aulas não foram conquistadas pelo professor de Educação Física, profissional que muito pleiteou para ministrá-las desde as séries iniciais do 10. grau. Elas vieram de uma forma política e serviram para "tapar buraco", como diz a professora Ephigênia.

*Secretaria Estadual de Educação de São Paulo. 
temos.

O professor Guilmar colocou sérias dúvidas a respeito do Ciclo Básico e que nós também as

Na jornada única do Ciclo Básico (6 horas), foram jogadas duas aulas de Educação Física e duas de Educação Artística, simplesmente porque o aluno teria que permanecer seis horas na Escola e a jornada do professor da classe seria menor que a do aluno. Então, quem iria cobrir esse espaço? 0 professor de Educação Física e o professor de Educação Artística. E o que aconteceu? Esses professores não estavam e nem foram preparados, na sua formação, para trabalhar com as crianças desta faixa etária, surgindo assim mais um problema da política educacional.

As escolas são ampliadas, os espaços físicos diminuem, os professores reclamam do material didático/pedagógico e até da quadra que não existe para trabalhar, é essa a realidade que enfrentamos na rede pública estadual, além da reivindicação salarial.

Gostaria também de salientar que são as tendências políticas que determinam a linha pedagógica que iremos utilizar, e assim todos que atuam na área da educação deveriam ter consciência dessa política. Se essa política está voltada para atender a demanda dos alunos e não para a qualidade de ensino, o que podemos fazer para melhorar essa política educacional? Devemos cobrar dos responsáveis os objetivos reais da Educação e que as verbas sejam aplicadas na escola e com o docente que nela trabalha.

Quanto à formação do profissional, existe uma diversificação nas grades curriculares das Faculdades de Educação Física e uma defasagem na formação do profissional para trabalhar na educação. O professor Guilmar e o professor Go Tani colocaram claramente que esta Faculdade agora e até o final dessa última década, estará voltada para a parte de docência desse professor, para a sua licenciatura e também para o professor que já está educando.

Quando o professor desconhece os objetivos da Educação e da Educação Física, ao elaborar seus planos de trabalho, o fará de forma copiada, repetitiva e sem continuidade. $O$ que é ministrado na 5a. série, irá se repetir na 6 a. e às vezes até no 20 . grau, sem a mínima profundidade e contextualização.

$O$ professor Guilmar colocou que as expectativas dos alunos são mínimas ao adentrar na Faculdade, pois de modo geral a procuram pela facilidade do curso. Eu também colocaria que uma expectativa é com relação ao clube que a Faculdade pode lhe proporcionar, onde o seu pensamento sobre o esporte se configura. Durante os quatro anos de Faculdade, o aluno tem no pensamento a especialização fora do país, a atuação em algum clube ou academia que lhe pague bem e por mil razões, alheias à própria vontade, ele acaba caindo na rede pública de ensino: Ao entrar numa escola pública ele encontra uma realidade bem diferente da vivida na universidade e sem saber como enfrentá-la, se torna um professor alheio, fazendo aquilo que bem entende, desenvolvendo o desporto que mais lhe convém, ou uma atividade fácil, ou seja, a que mais domina. Como resultado alguns alunos vão se desmotivando e se cansando, pois ao colocar o desporto na escola, quase sempre procurando um alto nível olímpico, nem os alunos e nem a escola estão preparados para isso, pois há falta de infra-estrutura material e humana. Num clube há médicos, psicólogos, técnicos e treinadores, além do ambiente e material propícios, na escola existe um professor, pouco espaço para treinar e alunos que nem sempre desejam ser atletas. Como disse o professor Guilmar: esse professor está "adestrando" o aluno, pois está exercitando o seu físico, mas o educador, está negando a criatividade do aluno.

A prática pedagógica do professor nem sempre condiz com a teoria, às vezes transmite os seus conhecimentos de uma forma mecanicista, sendo o melhor modelo de movimento, onde a função do aluno se restringe a imitá-lo. Quando só o físico é exercitado, estamos negando o conhecimento necessário para o aluno compreender o seu corpo, em se negando esse conhecimento e suas possibilidades, estaremos negligenciando a este corpo uma atuação na sociedade em que vive, podendo até vir a transformá-la.

Segundo a professora Anne Marie Seybold "vivemos uma época de excessos nos esportes, mas estéreis de movimentos, distante e alheio à saúde do corpo". Com essa frase posso esclarecer que a Educação Física na escola está voltada para o desporto e que com o excesso desse conteúdo, estaremos realmente negando a saúde do corpo. 
Gostaria de deixar claro que estamos preocupados com os métodos e técnicas importadas, quando deveríamos procurar a nossa técnica, a nossa Educação Física, considerando a nossa realidade política e as nossas particularidades culturais. Para tanto, acho que é necessário uma ação conjunta com as Universidades, como este Seminário, onde podemos debater a teoria e a realidade, levando-nos a alguns desequilíbrios e possivelmente a soluções. Nesta ação conjunta entre a Secretaria de Educação, a Universidade e a CENP, partindo das reflexões poderíamos traçar novos projetos. E nesses projetos a Coordenadoria de Estudos e Normas Pedagógicas (CENP) trabalharia com toda a rede pública para refletir essa prática pedagógica. Necessitamos dessa ação conjunta, porque capacitar 25 a 30 mil professores a responsabilidade é muito grande. Se dermos as mãos agora, chegaremos a um projeto pensado por várias instituições, que poderá através do conteúdo achar a significação da Educação Física Brasileira e ainda capacitar a contento, esses profissionais que se encontram na rede pública de ensino. 